\title{
Upaya Meningkatkan Kemampuan Bahasa Anak Usia 4-5 Tahun Melalui Metode Bernyanyi Menggunakan Media Kartu Gambar
}

\author{
Leli Fertiliana Dea ${ }^{1}$, Agus Setiawan ${ }^{2}$, dan Lina Asmiyati ${ }^{3}$ \\ 1,3 Program Studi PIAUD, Fakultas Tarbiyah, Institut Agama Islam Ma'arif NU Metro \\ Lampung \\ ${ }^{2}$ Program Studi Pendidikan Matematika, Fakultas Tarbiyah, Institut Agama Islam Ma'arif \\ NU Metro Lampung \\ e-mail corresponden: leli.f.dea@gmail.com¹,4905as@gmail.com², 4905as@gmail.com³
}

\begin{abstract}
ABSTRAK. Penelitian ini didasari oleh kemampuan bahasa pada anak usia 4-5 tahun di Raudlatul Athfal Al-Furqon Totokaton Punggur masih rendah, hal ini disebabkan latar belakang pendekatan pembelajaran kurang menarik, pemilihan metode pembelajaran bahasa yang kurang tepat, serta penyampaiannya yang kurang variatif dalam pembelajaran bahasa pada Anak Usia Dini. Guru juga kurang mengajarkan komponen bahasa secara menyeluruh. Hal ini berakibat pada nilai anak. Tujuan dari penelitian ini adalah kemampuan bahasa melalui metode bernyanyi menggunakan media kartu gambar pada anak usia 4-5 tahun di Raudlatul Athfal Al-Furqon Totokaton Punggur. Penelitian ini merupakan penelitian tindakan kelas (Action Classroom Research). Subjek penelitian ini yatiu 17 peserta didik usia 4-5 tahun di RA Al-Furqon Totokaton. Setelah peneliti melakukan penelitian, dan analisis data, peneliti mendapatkan data bahwa tidak ada anak dengan nilai bahasa BB (Belum Berkembang), 9 anak dengan penilaian bahasa MB (Mulai Berkembang atau sebesar 53\% dari jumlah anak, 4 anak dengan penilaian BSH (Berkembang Sesuai Harapan atau sebesar 23,5\% dari jumlah anak, dan 4 anak dengan penilaian bahasa BSB (Berkembang Sangat bagus) atau sebesar 23,5\% dari jumlah anak. Dapat disimpulkan bahwa melalui metode bernyanyi menggunakan media kartu gambar dapat meningkatkan kemampuan bahasa anak usia dini di Raudlatul Athfal Al-Furqon Totokaton Punggur tahun ajaran 2018/2019.
\end{abstract}

Kata Kunci : Bernyanyi, Kemampuan bahasa, Media Gambar.

ABSTRACT. This research is based on language skills in children aged 4-5 years at Raudlatul Athfal Al-Furqon Totokaton Punggur is still low, this is due to the background of the learning approach is less attractive, the selection of methods of language learning is not appropriate, and the delivery is less varied in language learning in Early Childhood. The teacher also does not teach the whole language component. This results in children's grades. The purpose of this study is the language skills that use the picture card media in children aged 4-5 years at Raudlatul Athfal Al-Furqon Totokaton Punggur. The subjects of this study were 17 students aged 4-5 years at RA Al-Furqon Totokaton. After the researchers conducted the study, and analyzed the data, the researchers obtained data that there were no children with $B B$ language scores (Not yet Developed), 9 children with MB language assessments (Starting to Develop or by 53\% of the number of children, 4 children with BSH ratings (Developing according Expectations or as much as 23.5\% of the total number of children, and 4 children with BSB language assessment (Very Good Development) or as much as $23.5 \%$ of the total number of children.It can be concluded that through the method of singing using picture card media can improve the language skills of early childhood at Raudlatul Athfal Al-Furqon Totokaton Punggur 2018/2019 school year.

Keyword : Singing, Language skills, Picture media 


\section{PENDAHULUAN}

Anak Usia Dini tergolong kategori anak prasekolah. Pada usia 0-6 tahun disebut golden age atau usia emas, dikarenakan pada usia ini, anak mengalami pertumbuhan dan perkembangan pesat pada setiap aspek perkembangannya. Dunia dan karakter Anak Usia Dini jauh berbeda dari orang dewasa. Anak Usia Dini bersifat egosentris, unik, mengekspresikan perilaku secara spontan, bersifat aktif dan energik, mempunyai rasa ingin tahu yang kuat dan antusias terhadap banyak hal, bersifat eksploratif, kaya dengan fantasi, mudah frustasi, kurang.pertimbangan dalam melakukan sesuatu, mempunyai daya perhatian yang pendek, mempunyai masa belajar yang paling potensial, berminat dengan teman[1]. Menurut Yuliani Nurani komponen kemampuan anak usia dini dalam disiplin keilmuan yang meliputi kemampuan matematika atau berhitung; sains; pengetahuan sosial; bahasa dan seni[2]. Pada masa perkembangannya, anak akan mengalami fase yang disebut dengan golden age. Fase ini merupakan tahap terpenting dalam perkembangan anak karena anak akan tumbuh dan berkembang dengan pesat. Fase ini merupakan peletak dasar untuk mengembangkan kemampuan kognitif, motorik, sosio emosional, agama, moral dan bahasa[3]. Pada anak usia dini, komunikasi harus selalu didampingi oleh orang tua ataupun orang dewasa. Hakikat Komunikasi adalah proses pernyatan antarmanusia. Yang dinyatakan itu adalah pikiran atau perasaan seseorang kepada orang lain dengan menggunakan bahasa sebagai penyalurnya[4]. Kecerdasan yang dimiliki Anak Usia Dini muncul dari sifat dan cirinya. Kecerdasan anak usia dini disebut multiple intelegency. Kecerdasan tersebut meliputi kecerdasan linguistik (bahasa), logika-matematika, visualspasial, gerak tubuh, musikal, interpersonal, intrapersonal, naturalis, dan spiritual[5]. Kecerdasan anak usia dini harus dirangsang agar siap menghadapi dunia di masa depannya dan menjadi seorang yang berilmu sehingga terangkatlah derajatnya, sesuai dengan firman Allah SWT. :

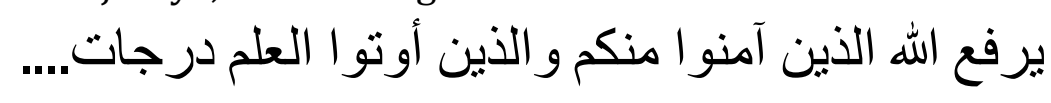

Artinya : Allah akan meningikan orang-orang yang beriman diantara kalian dan orang-orang yang diberi ilmu pengetahuan beberapa derajat...(al-qur'an surah almujaadalah : 11)[6].

Salah satu yang kecerdasan yang perlu dikembangkan adalah kecerdasan bahasa. Bahasa adalah alat untuk berpikir, mengekspresikan diri dan berkomunikasi. Bahasa mencakup setiap sarana komunikasi dengan menyimbolkan pikiran dan perasaan untuk menyampaikan makna kepada orang lain. Perkembangan kognitif dan perkembangan bahasa anak memiliki hubungan yang erat. Bahasa mempunyai peranan yang sangat penting terhadap proses berpikir anak. Dengan bahasa anak dapat lebih mudah memahami suatu informasi maupun kemampuan yang baru. Kemampuan berbahasa seseorang banyak dipengaruhi oleh kapasitas kemampuan kognitifnya. Besarnya kesempatan yang diperoleh untuk melakukan proses belajar dari lingkungannya mempengaruhi kemampuan berbahasa anak[7]. Menurut Hutterlocher, perkembangan bahasa paling cepat terjadi antara 2,5 sampai 5 tahun dibandingkan dengan masa toddler, dan perkembangan bahasa pada prasekolah lebih kompleks. Baik kemampuan kognitif maupun lingkungan terutama model peran yang konsisten, 
mempengaruhi perbendaharaan kata, percakapan dan pemahaman[8]. Dalam kamus besar Bahasa Indonesia, bahasa adalah sistem lambang bunyi yang arbitrer, digunakan oleh anggota suatu masyarakat untuk bekerja sama, berinteraksi, dan mengidentifikasikan diri[9]. Budi bahasa serta tutur kata menunjukkan sifat dan tabiat seseorang (baik buruk kelakuan menunjukkan tinggi rendah asal atau keturunan). Vygotsky dalam Ahmad Susanto yang dikutip dari Rusniah, bahasa adalah alat dalam mengekspresikan ide dan bertanya, bahasa juga menghasilkan konsep serta kategori berpikir [10]. Oleh sebab itu, bahasa adalah alat komunikasi yang sangat penting dalam kehidupan manusia. Melalui bahasa, manusia dapat saling bertegur sapa, dan bertukar pikiran. Hal ini juga terjadi pada Anak Usia Dini. Anak Usia Dini membutuhkan orang lain untuk mengungkapkan pikirannya melalui komunikasi atau bahasa. Mengungkapkan hal-hal yang ada di dalam rumah, di lingkungan sekitarnya, dan juga di sekolah.

Di dalam dunia sekolah yang berada di Indonesia, Bahasa Indonesia berfungsi sebagai pengantar di semua pendidikan dan jenjang sekolah mulai dari PAUD (Pendidikan Anak Usia Dini) atau RA (Raudlatul Athfal) hingga ke jenjang Perguruan Tinggi. Karena itu, bahasa berperan penting dalam pembaruan serta peningkatan mutu pendidikan[11]. Akan tetapi, mengembangkan kemampuan bahasa kepada Anak Usia Dini cukup sulit. Hal ini dikarenakan bahasa mempunyai komponen-komponen berupa kosakata, pengucapan, dan pemaknaan. Komponen-komponen tersebut harus diajarkan pada anak secara menyeluruh. Banyak gangguan yang timbul saat anak mulai mengembangkan kemampuan bahasa.

Menurut Kemp, Dkk yang dikutip dari Rohmani menyatakan jika gangguan berbahasa dan berkomunikasi dapat menghambat dalam memahami dan memproduksi bahasa. Kedua hal ini termasuk keluaran dari proses pengolahan informasi, pesan dan pikiran yang diikuti pemilihan kata yang tepat sehingga penjelasan secara verbal dapat dipahami lawan bicara[10]. Perkembangan Bahasa pada anak usia dini merupakan hal yang paling berfungsi dan berperan dalam kehidupan anak. Namun dengan adanya penggunaan gudged memiliki pengaruh terhadap keterampilan berbahasa anak yang mencakup dalam memperoleh keterampilan berbahasa, biasanya melalui suatu hubungan urutan yang teratur: pembiasaan pada masa kecil, belajar menyimak/mendengarkan bahasa, kemudian berbicara, membaca, dan menulis. Namun dengan menggunakan gudget berdampak terhadap keterlambatan dalam berbicara anak hal ini disebabkan karena gudget menghambat komunikasi langsung terhadap lingkungan sekitar[12]. Indikasi gangguan bahasa meliputi masalah bahasa verbal seperti halnya kesulitan menceritakan kembali suatu cerita, masalah kefasihan, kesulitan menangkap makna kata, membedakan kelas kata, memahami arahan, dll.

Kemudian, hambatan belajar dapat disebabkan ketidakmampuan dalam memproses informasi melalui masukan audio atau visual. Kemampuan mendengar atau mempersepsi audio dapat mempengaruhi keterampilan bahasa reseptif yang mencakup membaca, dan menulis. Kemampuan bahasa pada anak usia 4-5 tahun di Raudlatul Athfal AlFurqon Totokaton Punggur tergolong masih rendah, hal ini dikarenakan latar belakang pendekatan pembelajaran kurang menarik perhatian anak, pemilihan metode 
pembelajaran bahasa yang kurang tepat, serta penyampaiannya yang kurang variatif dalam pembelajaran bahasa pada Anak Usia Dini. Guru juga kurang mengajarkan komponen bahasa secara menyeluruh.

Hal ini diperkuat dengan hasil prasurvey yang dilakukan oleh peneliti seperti di bawah ini :

Tabel 1. Wawancara Prasurvey Penerapan Metode Bernyanyi

\begin{tabular}{|c|c|c|c|}
\hline \multirow{2}{*}{ No } & \multirow{2}{*}{ Aspek Penilaian } & \multicolumn{2}{|c|}{ Perlakuan } \\
\hline & & Sudah & Belum \\
\hline 1. & $\begin{array}{l}\text { Guru Mengetahui dengan jelas isi pokok materi yang akan } \\
\text { diajarkan. }\end{array}$ & $\sqrt{ }$ & \\
\hline 2. & $\begin{array}{l}\text { Guru Merumuskan dengan benar informasi/konsep materi } \\
\text { baru apa saja yang harus dikuasai oleh peserta didik. }\end{array}$ & $\sqrt{ }$ & \\
\hline 3. & $\begin{array}{l}\text { Guru Memilih nada lagu yang familiar di kalangan peserta } \\
\text { didik. }\end{array}$ & $\sqrt{ }$ & \\
\hline 4. & $\begin{array}{l}\text { Guru Menyusun informasi/konsep materi yang kita inginkan } \\
\text { untuk dikuasai peserta didik dalam bentuk lirik lagu yang } \\
\text { disesuaikan dengan nada lagu yang dipilih. }\end{array}$ & $\sqrt{ }$ & \\
\hline 5. & Guru Menyiapkan kartu gambar sesuai tema lagu. & & $\sqrt{ }$ \\
\hline 6. & $\begin{array}{l}\text { Guru Mempraktikkan terlebih dahulu dengan } \\
\text { menyanyikannya, sambil menunjukkan kartu gambar sesuai } \\
\text { cerita lagu. }\end{array}$ & & $\sqrt{ }$ \\
\hline 7. & $\begin{array}{l}\text { Guru Mendemonstrasikannya secara bersama-sama dan } \\
\text { berulang-ulang. }\end{array}$ & & $\sqrt{ }$ \\
\hline 8. & $\begin{array}{l}\text { Guru Mengusahakan untuk diikuti dengan gerak tubuh yang } \\
\text { sesuai. }\end{array}$ & & $\sqrt{ }$ \\
\hline 9. & $\begin{array}{l}\text { Guru Mengajukan pertanyaan seputar materi tersebut untuk } \\
\text { mengukur apakah siswa sudah dapat menguasai materi } \\
\text { kebahasaan melalui lagu yang dinyanyikan. }\end{array}$ & & $\sqrt{ }$ \\
\hline
\end{tabular}

(Sumber : Wawancara Dengan Ibu Dewi Agnggarini, S.pd, Guru/Wali Kelas A Anak Usia 4-5 tahun)

Dari tabel wawancara prasurvey dengan Ibu Dewi Anggarini, S.Pd. sebagai guru kelas, dapat dilihat bahwa terdapat 4 langkah yang sudah dilakukan guru, dan terdapat 5 langkah yang belum dilakukan dalam mengembangkan kemampuan bahasa pada anak. Selama ini guru sudah mengupayakkan untuk meningkatkan kemampuan bahasa pada anak usia 4-5 tahun, akan tetapi guru belum mengoptimalkan kemampuan tersebut dengan cara atau metode yang kreatif dan lebih menyenangkan. Hal ini berakibat pada nilai kemampuan bahasa anak.

Data yang diperoleh peneliti saat melakukan prasurvey penelitian pada anak yang dilaksanakan pada bulan September 2018 di Raudlatul Athfal AlFurqon Totokaton Punggur seperti pada tabel dibawah ini : 
Tabel 2. Data Prasurvey Kemampuan Bahasa Anak Usia 4-5 Tahun Di Raudlatul Athfal Al-Furqon Totokaton Punggur Bulan September 2018.

\begin{tabular}{|c|c|c|c|c|c|c|c|c|}
\hline \multirow{3}{*}{ No } & \multirow{3}{*}{ Nama } & \multicolumn{7}{|c|}{ Penilaian } \\
\hline & & \multicolumn{7}{|c|}{ Sesuai Indikator } \\
\hline & & 1 & 2 & 3 & 4 & 5 & 6 & Ket \\
\hline 1. & Siswa 1 & $\mathrm{BB}$ & $\mathrm{BB}$ & $\mathrm{BB}$ & MB & MB & MB & $\mathrm{BB}$ \\
\hline 2. & Siswa 2 & $\mathrm{BB}$ & $\mathrm{BB}$ & $\mathrm{BB}$ & MB & MB & MB & BB \\
\hline 3. & Siswa 3 & MB & MB & $\mathrm{BB}$ & $\mathrm{BB}$ & MB & MB & MB \\
\hline 4. & Siswa 4 & $\mathrm{BB}$ & MB & $\mathrm{BB}$ & MB & BB & $\mathrm{BB}$ & $\mathrm{BB}$ \\
\hline 5. & Siswa 5 & MB & MB & MB & MB & BB & BB & MB \\
\hline 6. & Siswa 6 & MB & MB & MB & $\mathrm{MB}$ & MB & MB & MB \\
\hline 7. & Siswa 7 & $\mathrm{MB}$ & MB & $\mathrm{BB}$ & $\mathrm{BB}$ & $\mathrm{MB}$ & $\mathrm{MB}$ & MB \\
\hline 8. & Siswa 8 & $\mathrm{MB}$ & $\mathrm{BB}$ & $\mathrm{MB}$ & $\mathrm{MB}$ & $\mathrm{MB}$ & $\mathrm{BB}$ & MB \\
\hline 9. & Siswa 9 & $\mathrm{BB}$ & $\mathrm{BB}$ & $\mathrm{BB}$ & MB & $\mathrm{BB}$ & $\mathrm{BB}$ & BB \\
\hline 10. & Siswa 10 & $\mathrm{BB}$ & $\mathrm{BB}$ & $\mathrm{BB}$ & BB & MB & MB & $\mathrm{BB}$ \\
\hline 11. & Siswa 11 & MB & $\mathrm{BB}$ & $\mathrm{BB}$ & MB & $\mathrm{MB}$ & $\mathrm{MB}$ & MB \\
\hline 12. & Siswa 12 & $\mathrm{BSH}$ & MB & $\mathrm{BSH}$ & MB & $\mathrm{BSH}$ & $\mathrm{BSH}$ & $\mathrm{BSH}$ \\
\hline 13. & Siswa 13 & $\mathrm{MB}$ & $\mathrm{MB}$ & $\mathrm{MB}$ & $\mathrm{BB}$ & $\mathrm{BB}$ & $\mathrm{BB}$ & $\mathrm{BB}$ \\
\hline 14. & Siswa 14 & $\mathrm{BSH}$ & $\mathrm{BSH}$ & $\mathrm{MB}$ & $\mathrm{BB}$ & $\mathrm{BSH}$ & $\mathrm{BSH}$ & $\mathrm{BSH}$ \\
\hline 15. & Siswa 15 & $\mathrm{BSH}$ & $\mathrm{BSH}$ & MB & $\mathrm{MB}$ & $\mathrm{BSH}$ & $\mathrm{BSH}$ & $\mathrm{BSH}$ \\
\hline 16. & Siswa 16 & BB & MB & BB & BB & $\mathrm{MB}$ & $\mathrm{MB}$ & $\mathrm{BB}$ \\
\hline 17. & Siswa 17 & $\mathrm{BB}$ & $\mathrm{BB}$ & $\mathrm{BB}$ & $\mathrm{BB}$ & $\mathrm{BB}$ & $\mathrm{BB}$ & BB \\
\hline
\end{tabular}

(Sumber : Dokumen Raudlatul Athfal Al-Furqon Totokaton Punggur)

Keterangan Indikator :

1 : Memahami bahasa seseptif (menyimak dan membaca).

2 : Menunjukan bahasa respektif (menyimak dan membaca).

3 : Memahami bahasa ekspresif (mengungkap bahasa secara verbal dan non verbal).

4 : Menunjukan kemampuan bahasa ekspresif (mengungkap bahasa secara verbal dan non verbal).

5 : Mengenal keaksaraan awal melalui bermain.

6 : Menunjukan kemampuan keaksaraan awal dalam berbagai bentuk karya

Keterangan nilai :

BB : Belum Berkembang

MB : Mulai Berkembang

BSH : Berkembang Sesuai Harapan

BSB : Berkembang Sangat Bagus

Dari tabel di atas dapat dilihat jika adanya 9 dari 17 anak (53\% dari jumlah anak) dengan penilaian bahasa belum berkembang (BB) atau anak melakukan dengan bimbingan dan contoh dari guru. Ada 5 anak (29\% dari jumlah anak) dengan penilaian bahasa mulai berkembang (MB) atau anak melakukan masih diingatkan dan dibantu guru. Ada 3 anak (18\% dari jumlah anak) dengan penilaian bahasa berkembang sesuai 
harapan (BSH) atau anak melakukan secara mandiri dan konsisten tanpa harus diingatkan dan dicontohkan guru. Dan belum ada anak dengan penilaian bahasa berkembang sangat bagus (BSB) atau anak melakukan secara mandiri dan konsisten tanpa harus di ingatkan dan dicontohkan oleh guru serta membantu temannya yang belum mencapai kemampuan sesuai indikator yang diharapkan.

Setelah mengadakan wawancara dengan Ibu dewi Anggarini, S.Pd pada bulan september 2018, diketahui jika terdapat faktor-faktor dari anak dengan kemampuan bahasa belum berkembang (BB). Adapun faktor-faktor tersebut adalah kurangnya perhatian dalam menyimak keterangan/informasi dari guru sehingga anak tidak bisa menjawab pertanyaan mengenai informasi tersebut. Adanya anak yang masih pendiam sehingga cukup sulit dalam menunjukkan kemampuan bahasa secara verbal maupun non verbal. Kemudian ada juga anak yang masih sulit mengucapakan kosa kata baru beserta pemahaman maknanya. Dan ada beberapa anak yang tidak tertarik dengan metode yang disampaikan guru.

Kemampuan bahasa anak usia 4-5 tahun di Raudlatul Athfal Al-Furqon masih banyak anak dengan nilai kemampuan bahasa BB (Belum Berkembang). Sedangkan pencapaian perkembangan yang diharapkan adalah BSB (Berkembang Sangat Bagus) atau anak mampu melakukan secara mandiri dan konsisten tanpa harus diingatkan dan dicontohkan oleh guru serta dapat membantu temannya yang belum mencapai kemampuan sesuai indikator yang diharapkan. Ada beberapa cara yang dapat digunakan untuk mengoptimalkan kecerdasan bahasa anak usia dini, antara lain dengan belajar berbicara di depan umum, mengarang, mendengarkan orang lain, banyak bergaul, belajar merangkai kata, banyak membaca, mendengarkan musik, dan bermain[1]. Salah satu metode meningkatkan kemampuan bahasa Anak Usia Dini yang tepat yaitu dengan mendengarkan musik (bernyanyi). "Bernyanyi adalah mengeluarkan suara dengan syair-syair yang dilagukan"[13].

Kegiatan yang sangat disukai oleh Anak Usia Dini adalah bernyanyi. Dengan bernyanyi, Anak Usia Dini bebas mengekspresikan diri, dan secara tidak langsung, juga dapat melatih olah vokal serta artikulasi bahasa. Selain dari pada itu, bernyanyi juga dapat digunakan untuk menambah pembendaharaan kata, dikarenakan saat anak bernyanyi, anak dapat mendengar dan menghafal kosa kata baru sehingga akan terangsang untuk mengungkapkanya. Bernyanyi juga dapat diartikan sebagai ekspresi bahasa. Sesuai pendapat Campbell dan Dollagan dalam Lilis Madyawati, dengan bernyanyi, anak dapat bergaya sesuka hati, dan mengucapkan kata-kata yang disenanginya dalam lagu yang dinyanyikan. Anak juga dapat berpikir kritis ketika memahami makna yang tertadap di dalam lagu sesuai dengan kehidupan nyata. Anak dapat menggunakan bahasa serta mengucapkannya dengan memahami maksud dari kata yang diucapkannya melalui contoh yang didengar dan dilihat dari lingkungan sekitarnya[1].

Penerapan metode bernyanyi berarti menciptakan serta mengelola pembelajaran dengan menggunakan syair-syair yang dilagukan. Syair tersebut dapat disesuaikan dengan materi yang akan diajarkan kepada anak. Menurut Syamsuri jari, manfaat penerapan metode bernyanyi adalah sarana relaksasi dengan menetralisasi 
denyut jantung dan gelombang otak, menumbuhkan minat dan memperkuat daya tarik pembelajaran, menciptakan proses pembelajaran lebih humanis dan menyenangkan, sebagai jembatan dalam mengingat materi pembelajaran, membangun retensi dan menyentuh emosi dan rasa estetika siswa, proses interrnalisasi nilai yang terdapat pada materi pembelajaran, dan mendorong motifasi anak[13].

Untuk mengoptimalkan upaya meningkatkan kemampuan bahasa melalui metode bernyanyi pada anak usia 4-5 tahun, penyampaian metode tersebut dibantu dengan metode tambahan yaitu menggunakan kartu gambar. Kartu gambar merupakan kartu yang berisi kata-kata dan terdapat gambar. Kartu gambar berfungsi sebagai stimulasi atau rangsangan munculnya ide, pikiran, maupun gagasan baru sehingga apa yang disampaikan memiliki kualitas yang baik, memiliki tujuan yang relevan, sederhana, dan menarik[1].

Menurut Pamadhi dalam Lilis, manfaat kartu gambar bagi anak adalah sebagai alat untuk mengungkapkan (mengekspresikan) isi hati, pendapat, serta gagasan. Kartu gambar juga bermanfaat sebagai media bermain fantasi, imajinasi, dan sublimasi anak, memstimulasi bentuk ketika lupa atau untuk menambahkan gagasan baru. Kartu gambar juga dapat digunakan sebagai alat untuk menjelaskan bentuk serta situasi[1].

\section{METODE}

Penelitian ini menggunakan rancangan penelitian tindakan kelas (PTK) yang terdiri dari dua sklus. Penelitian ini dilaksanakan di Raudlatul Athfal Al-Furqon Totokaton Punggur, Lampung. Subjek penelitian ini adalah Anak Usia 4-5 tahun sebanyak 17 anak. Metode pengumpulan data menggunakan toga metode yaitu lembar observasi, wawancara dan dokumentasi.

Analisis data dalam penelitian ini terdiri dari dua tahap. Analisis data pada tahap pertama, data diseleksi, difokuskan, dan ada yang direduksi, karena itu tahap ini disebut reduksi data. Kemudian data dikelompokan sesuai dengan hipotesis atau pertanyaan penelitian yang akan dicari jawabanya. Dan pada tahap kedua, data yang sudah dikelompokan akan dideskripsikan sehingga memiliki makna, baik dalam bentuk narasi, grafik, maupun tabel. Akhirnya berdasarkan deskripsi yang telah dibuat, ditarik kesimpulan dalam bentuk pernyataan[14]. Analisis ini digunakan untuk mengetahui hasil yang dilakukan oleh peneliti. Hal ini dilihat melalui berapa persen tingkat keberhasilan dengan menggunakan analisis presentase, yaitu :

$$
\mathrm{P}=\frac{\mathrm{F}}{\mathrm{N}} \times 100 \%
$$

Keterangan :

$\mathrm{P}=$ Persentase Kemampuan Bahasa Anak

$\mathrm{F}=$ Jumlah Anak Yang Mengalami Perubahan

$\mathrm{N}=$ Jumlah Anak Keseluruhan[15].

Dari pedoman di atas, maka diperoleh data perbandingan antara nilai rata-rata anak pada siklus I dan nilai rata-rata anak pada siklus II, serta persentase peningkatan kemampuan anak. Apabila nilai rata-rata pada siklus II lebih besar dari pada nilai rata- 
rata siklus I, dan jumlah persentase peningkatan kemampuan anak mengalami peningkatan pada siklus II, maka hasil penerapan metode menyanyi menggunakan kartu media untuk meningkatkan kemampuan bahasa pada anak usia 4-5 tahun meningkat (berhasil). Sedangkan apabila nilai rata-rata pada siklus I lebih besar dari pada nilai ratarata siklus II, dan jumlah persentase peningkatan kemampuan anak mengalami penurunan pada siklus II, maka hasil penerapan metode menyanyi menggunakan kartu media untuk meningkatkan kemampuan bahasa pada anak usia 4-5 tahun menurun (gagal).

\section{HASIL DAN PEMBAHASAN}

Hasil perkembangan kemampuan bahasa yang diperoleh pada siklus I ini mengalami peningkatan dibandingkan sebelum adanya tindakan. Hasil tersebut dapat dilihat dalam tabel berikut

Tabel 3. Perbandingan Penilaian Bahasa Pra Survey Dan Siklus I

\begin{tabular}{lcccc}
\hline \multirow{2}{*}{ Nilai } & \multicolumn{2}{c}{ Pra Survey } & \multicolumn{2}{c}{ Siklus I } \\
\cline { 2 - 5 } & Jumlah & persentase & Jumlah & persentase \\
\hline BB & 9 & $53 \%$ & 4 & $23,5 \%$ \\
\hline MB & 5 & $29 \%$ & 8 & $47 \%$ \\
\hline BSH & 3 & $18 \%$ & 4 & $23.5 \%$ \\
\hline BSB & 0 & $0 \%$ & 1 & $6 \%$ \\
Jumlah & $\mathbf{1 7}$ & $\mathbf{1 0 0 \%}$ & $\mathbf{1 7}$ & $\mathbf{1 0 0 \%}$ \\
\hline
\end{tabular}

Berdasarkan tabel di atas, dapat diketahui bahwa pada siklus I terdapat peningkatan hasil kemampuan perkembangan bahasa di Raudlatul Athfal Al-Furqon Totokaton Punggur terhadap anak usia 4-5 tahun. Dengan anak yang masuk dalam kriteria atau kategori BB (Belum Berkembang) atau anak masih memerlukan bimbingan dan contoh dari guru mengalami kenaikan menjadi hanya ada 4 anak dari 9 anak yang semula BB (Belum Berkembang). Kemudian anak yang masuk dalam kriteria MB (Mulai Berkembang) atau anak masih diingatkan dan dicontohkan oleh guru meningkat dari 5 anak menjadi 8 anak atau sebesar $47 \%$.

Anak yang masuk dalam kriteria BSH (Berkembang Sesuai Harapan) atau anak mulai mandiri dan konsisten tanpa harus diingatkan dan dicontohkan oleh guru meningkat dari 3 anak menjadi 4 anak atau sebesar 23,5\%. Sedangkan anak yang masuk dalam kriteria BSB (Berkembang Sangat Bagus) atau anak dapat mandiri serta konsisten tanpa harus diingatkan dan dicontohkan oleh guru serta dapat membantu temannya yang belum mampu dalam perkembangan sesuai indikator mendapatkan 1 anak dari yang awalnya tidak ada anak yang nilai bahsanya BSB.

Hasil perkembangan kemampuan bahasa yang diperoleh pada siklus II ini mengalami peningkatan dibandingkan siklus sebelumnya. Hasil tersebut dapat dilihat dalam tabel berikut: 
Tabel 4. Perbandingan Penilaian Bahasa Pra Survey, Siklus I, dan Siklus II

\begin{tabular}{ccccccc}
\hline \multirow{2}{*}{ Nilai } & \multicolumn{2}{c}{ Pra Survey } & \multicolumn{2}{c}{ Siklus I } & \multicolumn{2}{c}{ Siklus II } \\
\cline { 2 - 7 } & Jumlah & Persentase & Jumlah & Persentase & Jumlah & Persentase \\
\hline BB & 9 & $53 \%$ & 4 & $23,5 \%$ & 0 & $0 \%$ \\
\hline MB & 5 & $29 \%$ & 8 & $47 \%$ & 2 & $12 \%$ \\
\hline BSH & 3 & $18 \%$ & 4 & $23.5 \%$ & 11 & $64 \%$ \\
\hline BSB & 0 & $0 \%$ & 1 & $6 \%$ & 4 & $24 \%$ \\
\hline Jumlah & $\mathbf{1 7}$ & $\mathbf{1 0 0 \%}$ & $\mathbf{1 7}$ & $\mathbf{1 0 0 \%}$ & $\mathbf{1 7}$ & $\mathbf{1 0 0 \%}$ \\
\hline
\end{tabular}

Dilihat dari tabel di atas, serta berdasarkan wawancara dengan Ibu Dewi Anggarini, S.Pd dapat diketahui bahwa saat prasurvey terdapat 9 anak yang nilai bahasanya BB (Belum Berkembang), pada siklus I menjkadi 4 anak, dan pada siklus II tidak ada yang mendapat nilai BB (Belum Berkembang). Hal ini karena sudah tidak ada lagi anak yang memerlukan bimbingan dan contoh dari guru.

Kemudian dari 5 anak yang mendapat nilai MB (Mulai Berkembang) pada prasurvey menjadi 8 anak pada siklus I, dan pada siklus II hanya 2 anak yang nilai bahasanya MB (Mulai Berkembang) atau anak masih diingatkan dan dicontohkan oleh guru. Raditya naufal abiyu, ziyan algholi. Karena anak tersebut sudah mulai percaya diri untuk berekspresi tetapi masih perlu diingatkan dan dibantu oleh guru.

Terdapat peningkatan jumlah anak yang nilai bahasanya BSH (Berkembang Sesuai Harapan). Pada prasurvey hanya terdapat 3 anak yang nilai bahasanya BSH (Berkembang Sesuai Harapan), pada siklus I menjadi 4 anak, dan pada siklus II menjadi 11 anak yang nilai bahasanya BSH (Berkembang Sesuai Harapan) atau anak mulai mandiri dan konsisten tanpa harus diingatkan dan dicontohkan oleh guru. Hanya saja perbedaannya pada individu atau anak yang mendapatkan nilai BSH.

Kemampuan bahasa anak yang diperoleh dari sebelum diadakan tindakan (pra survey) dengan hasil akhir dari siklus I dan sikls II mengalami peningkatan. Hasil tersebut dapat dilihat dalam tabel dan grafik berikut ini:

Tabel 5. Perbandingan Penilaian Bahasa Pra Survey, Siklus I, Dan Siklus II

\begin{tabular}{lcccccc}
\hline \multirow{2}{*}{ Nilai } & \multicolumn{2}{c}{ Pra Survey } & \multicolumn{2}{c}{ Siklus I } & \multicolumn{2}{c}{ Siklus II } \\
\cline { 2 - 7 } & Jumlah & Persentase & Jumlah & Persentase & Jumlah & Persentase \\
\hline BB & 9 & $53 \%$ & 4 & $23,5 \%$ & 0 & $0 \%$ \\
\hline MB & 5 & $29 \%$ & 8 & $47 \%$ & 2 & $12 \%$ \\
\hline BSH & 3 & $18 \%$ & 4 & $23.5 \%$ & 11 & $64 \%$ \\
\hline BSB & 0 & $0 \%$ & 1 & $6 \%$ & 4 & $24 \%$ \\
\hline Jumlah & $\mathbf{1 7}$ & $\mathbf{1 0 0} \%$ & $\mathbf{1 7}$ & $\mathbf{1 0 0} \%$ & $\mathbf{1 7}$ & $\mathbf{1 0 0} \%$ \\
\hline
\end{tabular}


Gambar 1. Grafik Perbandingan Penilaian Bahasa Pra Survey, Siklus I, Dan Siklus II

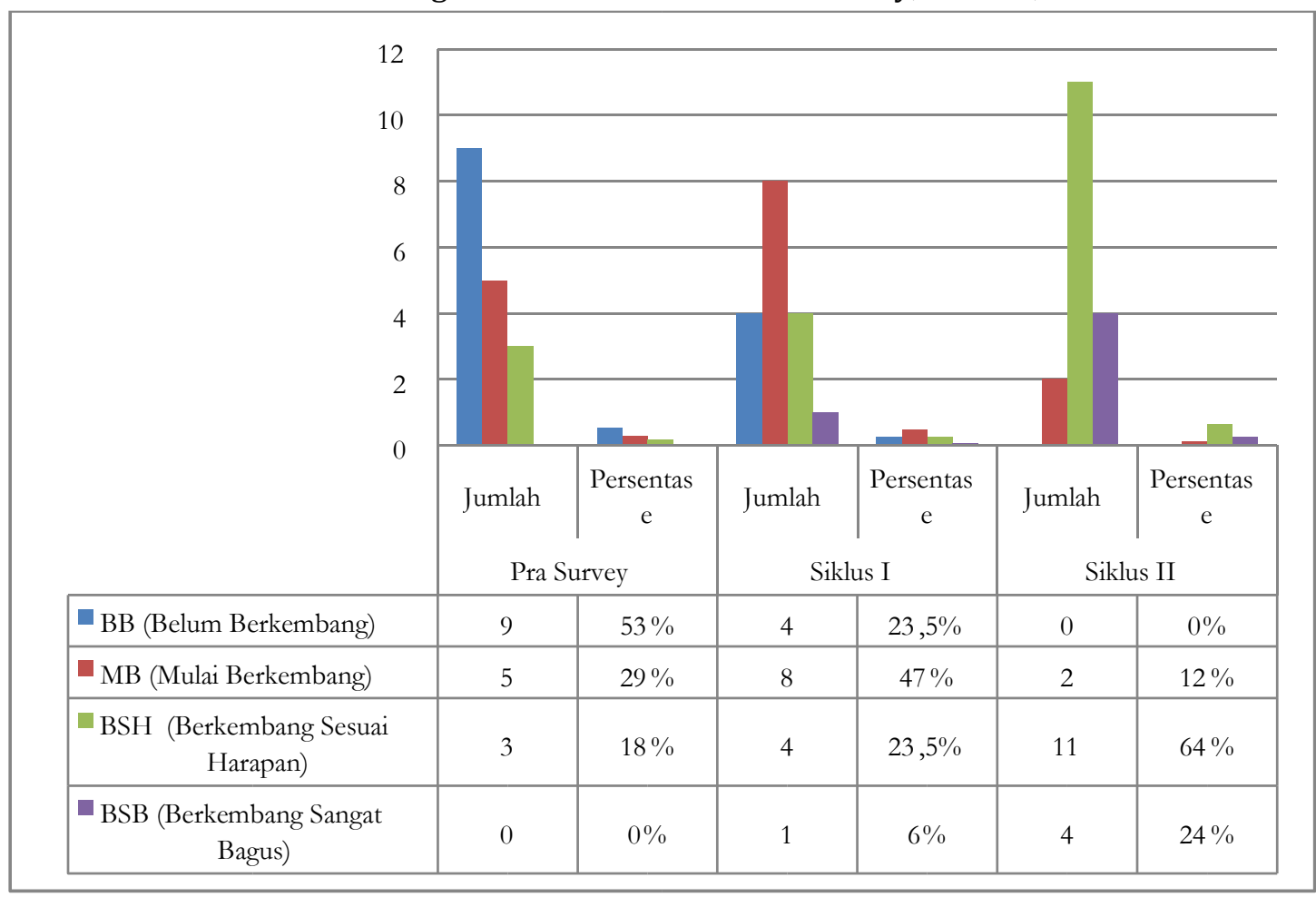

Dilihat dari data di atas, dapat diketahui bahwa saat prasurvey terdapat 9 anak yang nilai bahasanya BB (Belum Berkembang), pada siklus I menjadi 4 anak, dan pada siklus II tidak ada yang mendapat nilai BB (Belum Berkembang). Hal ini karena sudah tidak ada lagi anak yang memerlukan bimbingan dan contoh dari guru. Kemudian dari 5 anak yang mendapat nilai MB (Mulai Berkembang) pada prasurvey menjadi 8 anak pada siklus I, dan pada siklus II hanya 2 anak yang nilai bahasanya MB (Mulai Berkembang) atau anak masih diingatkan dan dicontohkan oleh guru. Terdapat peningkatan jumlah anak yang nilai bahasanya BSH (Berkembang Sesuai Harapan). Pada prasurvey hanya terdapat 3 anak yang nilai bahasanya BSH (Berkembang Sesuai Harapan), pada siklus I menjadi 4 anak, dan pada siklus II menjadi 11 anak yang nilai bahasanya BSH (Berkembang Sesuai Harapan) atau anak mulai mandiri dan konsisten tanpa harus diingatkan dan dicontohkan oleh guru. Selanjutnya terdapat peningkatan pada anak yang nilai bahasanya BSB (Berkembang Sesuai Harapan) atau sudah mandiri dan konsisten tanpa harus diingatkan dan dicontohkan oleh guru serta dapat membantu temannya yang belum mencapai kemampuan sesuai indikator yang diharapkan. Yang semula, saat prasurvey tidak ada anak yang nilai bahasanya BSB (Berkembang Sangat Bagus) pada siklus I terdapat 1 anak dan pada siklus II terdapat 4 anak.

\section{KESIMPULAN}

Berdasarkan pembahasan dapat diambil kesimpulan bahwa melalui metode bernyanyi menggunakan media kartu gambar dapat meningkatkan kemampuan bahasa anak usia dini di Raudlatul Athfal Al-Furqon Totokaton Punggur. Adapun cara 
meningkatkan kemampuan bahasa anak usia dini melalui metode bernyanyi menggunakan media kartu gambar di Raudlatul Athfal Al-Furqon Totokaton, yaitu, 1) Guru mengetahui dengan jelas isi pokok materi yang akan diajarkan. 2) Guru merumuskan dengan benar informasi/konsep materi baru apa saja yang harus dikuasai oleh peserta didik. 3) Guru memilih nada lagu yang familiar di kalangan peserta didik. 4) Guru menyusun informasi/konsep materi yang kita inginkan untuk dikuasai peserta didik dalam bentuk lirik lagu yang disesuaikan dengan nada lagu yang dipilih. 5) Guru menyiapkan kartu gambar sesuai tema lagu. 6) Guru harus mempraktikkan terlebih dahulu dengan menyanyikannya, sambil menunjukkan kartu gambar sesuai cerita lagu. 7) Guru mendemonstrasikannya secara bersama-sama dan berulang-ulang. 8) Guru mengusahakan untuk diikuti dengan gerak tubuh yang sesuai. 9) Guru mengajukan pertanyaan seputar materi tersebut untuk mengukur apakah siswa sudah dapat menguasai materi kebahasaan melalui lagu yang dinyanyikan tersebut. Hasil dari upaya meningkatkan bahasa anak usia dini melalui metode bernyanyi menggunakan kartu gambar pada anak usia 4-5 tahun di Raudlatul Athfal Al-Furqon Totokaton, yaitu 9 anak yang semula nilainya BB (Belum Berkembang), pada siklus I menjadi 4 anak atau sebesar $23.5 \%$ dari jumlah anak, dan pada siklus II tidak ada anak dengan nilai bahasa BB (Belum Berkembang). Dari 5 anak yang nilainya MB (Mulai Berkembang), pada siklus I naik menjadi 8 atau sebesar $47 \%$ dari jumlah anak, dan pada siklus II menjadi 2 anak atau sebesar $12 \%$ dari jumlah anak. Dan yang semula belum ada anak yang mendapat nilai BSB (Berkembang Sangat Bagus) setelah ada tindakan pada siklus I terdapat 1 anak yang nilai bahasanya Berkembang Sangat Bagus (BSB) atau sebesar 6\% dari jumlah anak, dan pada siklus II naik menjadi 4 anak atau sebesar $24 \%$ dari jumlah anak.

\section{REFERENSI}

[1] L. Madyawati, Strategi pengembangan bahasa pada anak. Kencana, 2016.

[2] La Ode Anhusadar, "Assessment Dalam Pendidikan Anak Usia Dini," Al-Ta'dib, vol. 6, no. 1, 2013.

[3] Anita, "Perkembangan Bahasa Anak Usia Dini," J. al-Shifa, vol. 06, no. 02, pp. 161180, 2015.

[4] R. P. Hermayo, "Membentuk Komunikasi Yang Efektif Pada Masa Perkembangan Anak Usia Dini," J. Pedagog., vol. 1, no. 1, pp. 1-22, 2014.

[5] L. F. Dea and A. Setiawan, "Penerapan metode bermain jari tangan dalam mengembangkan kemampuan kognitif pada anak kelas a di raudhatul athfal ma'arif 01 metro," Thufuli J. Ilm. Pendidik. Islam Anak Usia Dini, vol. 1, no. 1, pp. 21-34, 2019.

[6] Departemen Agama RI, Al-Qur'an Terjemahan. Bandung: CV Darussunah, 2015.

[7] N. Sa'ida, "Bahasa Sebagai Salah Satu Sistem Kognitif Anak Usia Dini," Pedagog. J. Anak Usia Dini dan Pendidik. Anak Usia Dini, vol. 4, no. 2, p. 16, Oct. 2018.

[8] Joni, "Hubungan pola asuh orang tua terhadap perkembangan bahasa anak prasekolah," J. paud tambusai, vol. 1, no. 6, pp. 42-48, 2015.

[9] M. Dewi and others, "Penerapan Metode Bernyanyi untuk Meningkatkan Daya Ingat Anak dalam Pengenalan Huruf Hijaiyyah di TPA Darul Falah Gampong Pineung," UIN AR-Raniry Banda Aceh, 2017. 
[10] Rohmani Nur Indah, "Gangguan berbahasa: Kajian pengantar.” UIN-Maliki Press, 2017.

[11] T. Astuti, Konsep Kemampuan Dan Perkembangan Bahasa AUD. Padang: Universitas Negeri Padang, 2015.

[12] Y. Yulsyofriend, V. Anggraini, and I. Yeni, "Dampak Gudget Terhadap Perkembangan Bahasa Anak Usia Dini," Pedagog. J. Anak Usia Dini dan Pendidik. Anak Usia Dini, vol. 5, no. 1, p. 25, Jul. 2019.

[13] M. Fadlillah and others, Edutainment Pendidikan Anak Usia Dini: Menciptakan Pembelajaran Menarik, Kreatif dan Menyenangkan. Prenada Media, 2016.

[14] W. Kuswaya and I. Wardani, "Penelitian Tindakan Kelas," Jakarta Univ. Terbuka, 2008.

[15] A. Setiawan, "Pembelajaran Matematika Dasar Berintegrasi Keislaman Untuk Meningkatkan Sikap Religiusitas Siswa," 2019. 